\title{
The Role of Taxation Education on Taxation Knowledge and Its Effect on Tax Fairness as well as Tax Compliance on Handicraft SMEs Sectors in Indonesia
}

\author{
Imam Mukhlis ${ }^{1}$, Sugeng Hadi Utomo ${ }^{1} \&$ Yuli Soesetio ${ }^{1}$ \\ ${ }^{1}$ Faculty of Economics, State University of Malang, Indonesia \\ Correspondence: Imam Mukhlis, Faculty of Economics, State University of Malang, Malang, East Java, Indonesia. \\ Tel: 62-341-552-888.
}

Received: August 23, 2015

Accepted: September 15, $2015 \quad$ Online Published: October 7, 2015

doi:10.5430/ijfr.v6n4p161

URL: http://dx.doi.org/10.5430/ijfr.v6n4p161

\begin{abstract}
This study aims to analyze the role of taxation education on the tax knowledge and its impact on tax fairness and tax compliance of handicraft SME sector in Indonesia. The unit of analysis is handicraft SMEs businessman located in the district / city in the province of East Java, Indonesia. The type of data is primary data obtained through a questionnaire technique. Samples were obtained from a population sample that is taken with a multistage method with simple random sampling technique. While the data analysis method used is the analysis of Structural Equation Modeling by using Partial Least Square.

The study provides conclusions, namely; tax education has a positive and significant impact on tax knowledge, tax knowledge has a significant and positive effect on tax fairness, tax fairness has a significant positive effect on tax compliance and tax knowledge has a significant and positive effect on tax compliance. Based on these results, the strengthening of the tax education is very important in shaping the tax knowledge, so that it can increase tax compliance. In this case the tax socialization efforts can be done through the dissemination of information about the types of taxes, tax rates, and tax payment mechanisms.
\end{abstract}

Keywords: tax knowledge, tax compliance, partial least square, SMEs

\section{Introduction}

The existence of the SME sector has an important role in promoting economic growth and equitable distribution of economic activities. The role can be seen from the ability in employment, purchasing power of creation, processing local raw material, and an increase in tax revenue. In Indonesia, until the year of 2012 there were 56,534,592 of SME business units. This amount of SME could absorb 107,657,509 labor (www.depkop.go.id). The spread of SMEs in Indonesia is speeded out in various regions with a variety of products that has been produced. This SMEs business sectors consists of; food and beverages, handicrafts, household appliances, and textiles.

One of the provinces in Indonesia which has a pretty good development of SMEs is the province of East Java. As known, East Java is one of the provinces that have economic growth above-average growth of the national economy. In connection with the development of the SME sector in East Java in 2012 amounted to 4.2 million units (ekonomibisnis.suarasurabaya.net). The amount is spread over 38 districts / municipalities. Meanwhile, the type of businesses consists of food and beverage businesses, crafts, industry, agriculture and processing.

The continued development of SME sector in the regional economy can be a source of tax revenue for financing national development. In this case, the potential revenue of substantial tax from the SME sector, providing an opportunity for the state to impose a tax on the SME sector. In connection with this, the Government of Indonesia issued Government Regulation No.46 Year 2013 regarding Income Tax on Business Income from Received or Retrieved Taxpayers Who Have Specific Gross Circulation. On income from businesses received or earned taxpayer who has a certain gross income, subject to final income tax. The amount of income tax rate that is final is $1 \%$ (one percent) of SMEs with a turnover of Rp 0 to $\mathrm{Rp} 4.8$ billion per year.

Implementation of government regulation that has caused controversy among the public, because it is contrary to the spirit of supporting the growth of micro and small businesses, as mandated in Law No. 20 Year 2008 concerning the 
SMEs. Even the Ministry of Cooperatives and Small and Medium Enterprises (SMEs) ask for restrictions SMEs are taxable if turnover exceeds USD 200 million. If the turnover is below Rp200 million, the Ministry of Cooperatives and SMEs worry will turn off the small entrepreneurs.

The resistance of businessmen linked to the imposition of SMEs final income tax of $1 \%$ of the show is the asymmetric information. This can happen because tida the same understanding of the imposition of income tax on small businesses with a turnover of between Rp.0 value up to Rp. 4.8 billion per year. It happen asymmetric information between agent and principle in the field of taxation. On the one hand, the government is oriented towards the increase in state tax revenue and on the other hand small businesses oriented to operations and business continuity. In this case both parties have different views and interests in relation to the taxation of such income.

Based on the above conditions, taxation always raises the pros and cons. This can happen because it involves aspects of justice and tax knowledge, thus affecting the level of tax compliance of taxpayers. In this case the level of tax compliance entrepreneurs SME sector can contribute quite a large increase in state tax revenue. Based on a theoretical perspective suggests that tax compliance can be built on economic factors, educational factors and psychological factors. This provides evidence that the level of tax compliance can not be left alone in the business activities of the taxpayer. The existence of sanctions and penalties from tax authorities relating to tax non-compliance is expected to provide increased awareness of the taxpayer against the tax liability accordingly. However, it is important for all parties to pay attention to aspects of tax and tax justice felt by taxpayers. Both aspects are believed to play an important role in influencing the level of tax compliance businesses SME sector.

In relation to the factors that affect tax compliance, tax fairness and tax knowledge has an important role. In relation to tax fairness, according to Benk et al (2012) there are five dimensions in tax fairness, namely: general fairness, middle income tax earners share/burden, tax rate structure, special provisions, and tax system of equality/inequality. Among the five dimensions of tax fairness can be formed by the generally accepted indicator justice/perceived by the taxpayer. Meawhile, the tax knowledge with regard to the public's understanding of the tax and several matters relating to the taxation system applied. In this case the tax knowledge is strongly influenced by the education level of taxation that is perceived by the public. In his research Mukhlis et al (2013) concluded that basically the SME sector businesses can understand their tax obligations when there is the aspect of justice and tax benefit can be received in real terms by businesses in the SME sector in East Java. Therefore, the research results done by Mukasa (2011) gave the result that the tax knowledge and perceived fairness taxes have a causal relationship with tax compliance. Therefore, it is important to analyze the role of education as far as the role of the tax, the tax knowledge and a sense of justice taxpayer to tax compliance businesses, especially SMEs crafts field in East Java.

\section{Formulation of the Problem}

Based on the above explanation, the formulation of the problem is:

(1) How big does the effect of the taxation education on taxation knowledge for SME businesses sector?

(2) How big does the effect of tax knowledge of the sense of tax fairness for the SME businesses sector?

(3) How big does the effect of the tax fairness on tax compliance for the SME businesses sector?

(4) How big does the effect of tax knowledge on tax compliance for the SME businesses sector?

\section{Theoretical Framework}

Theory of tax compliance by Allingham and Sandmo (1972) was originally declared as a person who has a declared income tax obligations. In this case, the declared income can be affected by the amount of income, tax rate, the possibility to do the audit and the penalty rate. Based on the model, a decision the taxpayer can be written as follows (Das-Gupta, 2014):

$$
\begin{gathered}
\operatorname{Max} \mathrm{E}(\mathrm{U})=(1-\mathrm{p}) \mathrm{U}(\mathrm{YN})+\mathrm{PU}(\mathrm{Yc}) \\
\mathrm{YN}=\mathrm{Y}-\mathrm{TXY} \\
\mathrm{YC}=\mathrm{Y}-\mathrm{TXY}-(1+\pi)(1-\mathrm{x}) \mathrm{tY}
\end{gathered}
$$

In which:

$\mathrm{Y}=$ income to declare to the tax authorities to maximize her expected utility of income.

$\mathrm{T}(\mathrm{Y})=$ income tax function,

$\pi=$ the penalty rate on detected but underpaid taxes,

$\mathrm{p}=$ and the probability of tax audits and detection, 
$\mathrm{x}=$ the fraction of income reported voluntarily to the tax authorities (or the level of compliance)

In applying the tax for the SMEs businessmen, according to Kamleitner et al (2012) there are three main aspects that affect tax compliance business, namely; perceived opportunity, knowledge requirements, and decisions frames. These three factors are also associated with private businesses as concerning aspects; gender, age, personality, fairness perceptions, and cultural differences. Beside that is also influenced by environmental growing industries, such as: Specific of industry, business size, jurisdictions, and group norms.

Various studies have been conducted to estimate the factors that influence tax compliance. Results of research conducted by the Marti and Wanjohi (2010) in Kenya provided conclusions about the need for a fair tax system that ensures people to carry out the voluntary tax obligations. Palil and Mustopha (2011) as well as Saad (2011) led to the conclusion about the tax education in building knowledge and perceptions of fairness of tax community in Malaysia and New Zealand. This is important because it is through the justice community will be able to be moved in meeting their tax obligations. Kołodziej (2011) in his study also concluded that the tax education is an important factor that can influence the behavior of taxpayers. In this case the tax education can be affected by how much knowledge the public about taxes (tax knowledge). Atawodi and Ojeka (2012) in their research concluded that the problem of high rates and complex tax administration so that SMEs in Nigeria disobedient taxes. While research by Mukhlis, et al (2013) study concluded that basically businessmen are willing to fulfill their tax obligations and benefits as long as the justice of the taxes that have been paid.

\section{Research Method}

This type of research is explanatory to explain the relationship between variables. The data used in this research is primary data obtained through the questionnaire technique. The research activities carried out in March-June 2015. The population in this study is the entrepreneurs in SME sector in the field of handicrafts districts/cities in East Java. Furthermore, the unit of analysis in this study is the handicraft entrepreneurs in SME sector. The technique of sampling was done by multistage sampling (Iyoke, 2006). Techniques have been due to the large object, thus requiring sampling methods that are efficient and representative. This technique is done by through phasing in the sampling. The first stage of sampling (first stage sampling) is done by purposive sampling method. How this is done by determining district/city in East Java, which is considered to represent the presence of SMEs in East Java crafts. The criteria for purposive samples taken are: to have a representation/district/city, has the potential to export abroad, the business developed on a small scale, micro and medium. The second sampling stage was done with a simple random sampling method. This method was taken through taking random SMEs handicraft businesses in various districts/cities that have been determined.

To answer the problem of study formulation, the data analysis method used in this research is the Structural Equation Models analysis by using Partial Least Square (PLS) approach. This analysis is used to examine relationships between variables studied structured in accordance with the formulation of research problems. Whereas in the processing data using Smart PLS program version 2.

In order to facilitate the problem solving of this research, it is necessary to develop a research design. In this case the design of the study describes the patterns of relationships between variables, the direction of the relationship between variables and variable types. In this research, design research to develop a model of a model adopted compliance of various existing studies. In terms of tax fairness, the indicators used in this study developed a model of tax fairness developed by Gerbing (1988), Azmi and Perumal (2008), and Benk, et al (2012). Tax education in this study is to develop research done by Richardson and Sawyer (2001). Tax knowledge is to develop research done by Eriksen and Fallan (1996). Meanwhile, the level of tax compliance that has been developed in this research was conducted by Simanjutak and Mukhlis (2012).

The description of the variables used in this study is: 
Table 1. Research variable description

\begin{tabular}{lll}
\hline Variabel & Variable/Indicator & Variable Type \\
\hline X1: & Taxation Education & Independent \\
\hline X11: & Socialization on right and obligation of tax & \\
\hline X12: & Socialization on the tax function and penalty & \\
\hline X13: & Socialization on tax type and tariff \\
\hline X14: & Socialization on tax mechanism and payment \\
\hline X15: & Socialization on tax measurement \\
\hline
\end{tabular}

\begin{tabular}{ll}
\hline Y1: & Taxation Knowledge \\
\hline Y11: & Knowledge on right and obligation of tax \\
\hline Y12: & Knowledge on the tax function and penalty \\
\hline Y13: & Knowledge on tax type and tariff \\
\hline Y14: & Knowledge on tax mechanism and payment \\
\hline Y15: & Knowledge on tax measurement \\
\hline
\end{tabular}

\begin{tabular}{lll}
\hline Y2: & Tax Justice & Intervening \\
\hline Y21: & General Justice Umum & \\
\hline Y22: & Personal Interest \\
\hline Y23: & Specific Rules on Wealth \\
\hline Y24: & Tax Tariff \\
\hline Y25: & Government Feedback \\
\hline
\end{tabular}

\begin{tabular}{lll}
\hline Y3: & Tax Compliance & Dependent \\
\hline Y31: & Timeliness for tax payment & \\
\hline Y32: & Obedience in tax payment & \\
Y33: & Timeliness in delivering SPT & \\
\hline
\end{tabular}

\section{Analysis Results}

Based on the results of data processing, it can be explained that many respondents were sent a questionnaire that returns as much as 200 units of the questionnaire. Out of those 200 questionnaires, there were 183 eligible questionnaires which can be used as samples and ere filled out by the respondent who are the SMEs handicraft businesses who are still operating in generating output. The respondents are spread in 26 districts / cities in East Java province, Indonesia. The distribution of survey respondents by district / city as follows:

Table 2. Research respondents based on area in regency/city in East Java, Indonesia in 2015

\begin{tabular}{llrr}
\hline No & Regency / & $\begin{array}{r}\text { Number of } \\
\text { Respondent (person) }\end{array}$ & $\begin{array}{r}\text { Percentage } \\
(\%)\end{array}$ \\
\hline 1 & Malang City & 22 & 12.0 \\
\hline 2 & Regency Bojonegoro & 6 & 3.3 \\
\hline 3 & Kediri City & 9 & 4.9 \\
\hline 4 & Probolinggo Regency & 7 & 3.8 \\
\hline
\end{tabular}




\begin{tabular}{llrr}
\hline 5 & Tulungagung Regency & 9 & 4.9 \\
\hline 6 & Kediri Regency & 15 & 8.2 \\
\hline 7 & Bondowoso Regency & 4 & 2.2 \\
\hline 8 & Trenggalek Regency & 5 & 1.1 \\
\hline 9 & Jombang Regency & 25 & 2.2 \\
\hline 10 & Malang Regency & 8 & 13.7 \\
\hline 11 & Mojokerto Regency & 4 & 4.4 \\
\hline 12 & Lumajang Regency & 8 & 2.2 \\
\hline 13 & Banyuwangi Regency & 6 & 4.4 \\
\hline 14 & Probolinggo City & 8 & 3.3 \\
\hline 15 & Ponorogo Regency & 6 & 4.4 \\
\hline 16 & Nganjuk Regency & 15 & 3.3 \\
\hline 17 & Pasuruan Regency & 4 & 8.2 \\
\hline 18 & Sidoarjo Regency & 4 & 2.2 \\
\hline 19 & Surabaya City & 1 & 2.2 \\
\hline 20 & Batu City & 4 & 0.5 \\
\hline 21 & Lamongan Regency & 4 & 2.2 \\
\hline 22 & Tuban Regency & 3 & 2.2 \\
\hline 23 & Pasuruan City & 2 & 1.6 \\
\hline 24 & Blitar Regency & 1 & 1.1 \\
\hline 25 & Magetan Regency & 1 & 0.5 \\
\hline 26 & Madiun Regency & 183 & 0.5 \\
\hline & Total & 100 \\
\hline
\end{tabular}

Data Source: Primary, Processed

Based on the observations and data collection, it showed that Malang has the largest number of respondents which are 25 respondents (13.7\%) of handicraft entrepreneurs on SME sector. The biggest number of respondents is also in Malang, which reached 22 businesses (12\%). Meanwhile, the smallest number of respondents is 1 respondent $(0.5 \%)$ including in Magetan Regency, Madiun Regency and in Batu City. The average, based on the scope of the area average respondent every region of 7 businesses SME sector (3.8\%). Area that has the research samples above represents the area of East Java Province which consists of industry areas, agriculture, farming, forestry, and marine. Areas such as research areas are buffers East Java economy in the constellation of national economy and the international economy.

To answer the problem of this formulation of this study, we analyze the structural equation modeling (Structural Equation Model) by using Partial Least Square. The results of data processing can be seen in the following tables and figures:

Table 3. Inner model t-statistic

\begin{tabular}{llll}
\hline & Justice & Compliance & Education Knowledge \\
\hline Justice & & 5.446954 & \\
\hline Compliance & & & \\
\hline Education & & & 11.392681 \\
\hline Knowledge & 10.813205 & 3.206695 & \\
\hline
\end{tabular}

Source: Processed Data 
Table 4. Outer model t-statistic

\begin{tabular}{|c|c|c|c|}
\hline & Justice & Compliance & Education Knowledge \\
\hline $\mathrm{X} 11$ & & & 38.680277 \\
\hline $\mathrm{x} 12$ & & & 28.002499 \\
\hline $\mathrm{x} 13$ & & & 29.084284 \\
\hline $\mathrm{x} 14$ & & & 53.111772 \\
\hline $\mathrm{x} 15$ & & & 23.898159 \\
\hline y11 & & & 40.012223 \\
\hline y12 & & & 24.883073 \\
\hline y13 & & & 35.055890 \\
\hline y14 & & & 54.520454 \\
\hline $\mathrm{y} 15$ & & & 25.102572 \\
\hline y21 & 29.215769 & & \\
\hline y22 & 9.421267 & & \\
\hline y23 & 37.310689 & & \\
\hline $\mathrm{y} 24$ & 30.908530 & & \\
\hline$y 25$ & 16.821962 & & \\
\hline $\mathrm{y} 31$ & & 75.832216 & \\
\hline $\mathrm{y} 32$ & & 93.218465 & \\
\hline y33 & & 82.570188 & \\
\hline
\end{tabular}

Source: Processed Data

Table 5. The value of t-Statistic

\begin{tabular}{|c|c|c|}
\hline Hypothesis & Correlation between variables & t Statistics $(|\mathrm{O} / \mathrm{STERR}|)$ \\
\hline $\mathrm{H}_{1}$ & Justice -> Compliance & 5.446954 \\
\hline $\mathrm{H}_{2}$ & Education $->$ Knowledge & 11.392681 \\
\hline $\mathrm{H}_{3}$ & Knowledge $\quad->$ Justice & 10.813205 \\
\hline $\mathrm{H}_{4}$ & Knowledge $->$ Compliance & 3.206695 \\
\hline
\end{tabular}

\section{Source: Processed Data}

Based on the data processing, it shows the result of the T-test is high. This high value has meaning tendency of its significance from various variables that are measured through the existing indicators which have correlation from each variable. Therefore, the path analysis result can be seen on this following path diagram: 


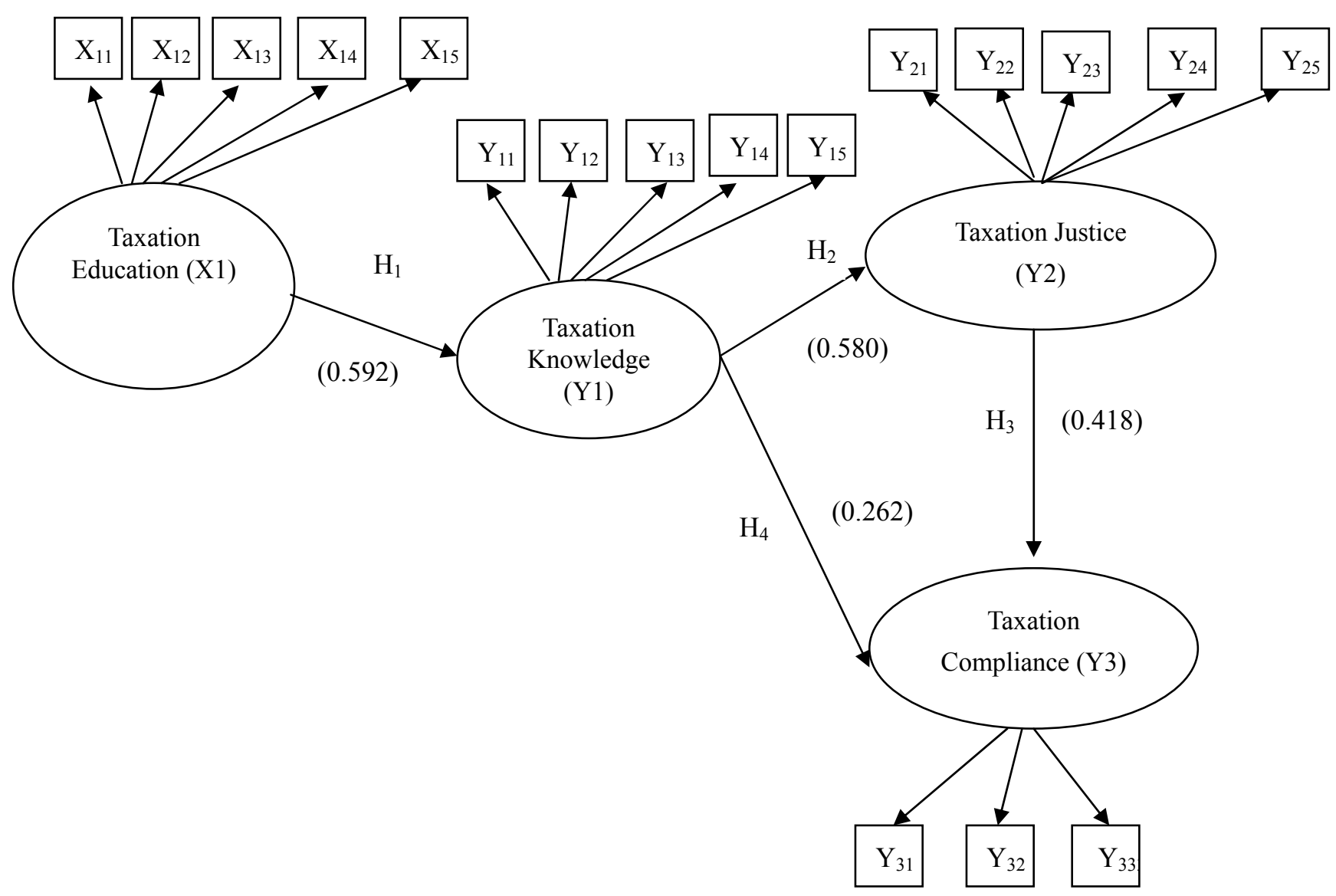

Description: The number inside the bracket shows the coefficient value between variable

Figure 1. Path analysis diagram for tax compliance of SME business

Based on the above data processing results, it indicated that there is a relationship between the variables studied. In this case, the tax education has a positive and significant impact on the tax knowledge with a coefficient value of 0.592, tax knowledge has a significant and positive effect on tax justice with coefficient of 0.580 , tax fairness positive and significant impact on tax compliance with coefficient value of 0.418 , and the knowledge tax and significant positive effect on tax compliance with coefficient of 0.262 . These results provide confirmation of the importance of tax education in an effort to improve tax compliance. Tax education will both be able to build a good foundation of knowledge taxation also to society. The higher the tax knowledge of the society, the higher it will be able to have a significant influence on the achievement of a sense of tax justice for the community. The higher sense of justice taxes received by the community, then it will be able to increase tax compliance community. Similarly, the level of knowledge of the higher taxes, then it will be able to make people aware of their tax obligations. Taxation knowledge can be built from the tax education received by the community.

In this case, according to Hofmann, et al (2008) and Mohd (2005), an important factor affecting tax compliance is tax knowledge. Tax knowledge is related to the tax law. As known that tax is highly associated with various tax rules, types of taxes, the object of taxation, tariffs, penalties, fines, all of which may be implicated in the realm of law. In this case the tax law can set various things into formal legal basis in taxation. Poor knowledge about taxes can lead to distrust and negative attitudes towards taxes. While the knowledge of good tax correlated with a positive attitude towards tax (Niemirowski, et al, 2002). In this case, according to Eriksen and Fallan (1996) when the level of knowledge of the tax increases, the rate of decline of tax evasion and tax compliance levels to be much higher.

Other factors that could affect tax compliance are a tax justice perceived by the public. In this case, according to Hofmann, et al (2008) justice related to the perceived balance of taxes paid and received public goods, and the perceived fairness of the procedure and the consequences of violation of norms. In relation to tax behavior Wenzel (2003) justifies includes tax justice: distributive justice, procedural justice and retributive justice. 
For SME sector businesses, especially in the field of handicrafts in East Java will face the challenges and opportunities in business development in this era of ASEAN Economic Community in 2015. The high level of competition commodities produced in various countries of ASEAN has consequences on the endurance capacity of handicraft businesses to continue producing. The existence of the tax on business activities in the SME sector, it should be understood as part of the challenges and opportunities for the SME sector in winning the competition. On the other hand, SMEs businesses deposited as good citizens have an obligation in the fulfillment of tax obligations in accordance with applicable regulations. However, on the other hand, the tax paid by businesses in the SME sector should be re-restored in the form of physical infrastructure that can facilitate business and reduce economic costs. Therefore, tax compliance businesses SME sector in the field of handicrafts in districts / cities in East Java is basically an important factor that can push the level of business success in the era of global economic in ASEAN.

\section{Conclusion and Recommendations}

The existence of SME business sector, particularly in the field of handicrafts plays an important role in regional economic development in the district / city in East Java and also the national economy. Beside that, SME sector can also play an important role in increasing tax revenue. The continued development of SME sector can contribute in increasing the state tax revenue. In relation to the tax revenue, tax compliance factors play an important role in increasing tax revenue. Results of a study of 183 businesses SME sector in the field of handicrafts in districts / cities in East Java gives the conclusion that tax education has a positive and significant effect on tax knowledge, tax knowledge has a significant and positive effect on tax justice, tax justice has a significant and positive effect on tax compliance and tax knowledge and has a significant positive effect on tax compliance. Based on these results, strengthening of the tax education is very important in shaping the tax knowledge, so that it can increase tax compliance. In this case, the tax socialization efforts can be done through the dissemination of information about the types of taxes, tax rates, tax payment mechanisms and tax benefits.

\section{References}

Allingham, M. G., \& Agnar Sandmo. (1972). Income Tax Evasion: A Theoritical Analysis. Journal of Public Economics, 1, 323-338. http://dx.doi.org/10.1016/0047-2727(72)90010-2

Atawodi, Ojochogwu Winnie, \& Stephen Aanu Ojeka. (2012). Factors That Affect Tax Compliance among Small and Medium Enterprises (SMEs) in North Central Nigeria. International Journal of Business and Management, 7(12), 87-96. http://dx.doi.org/10.5539/ijbm.v7n12p87

Azmi, Anna A. Che, \& Kamala A., Perumal. (2008). TaxFairness Dimensions in an Asian Context: The Malaysian Perspective. International Review of Business Research Papers, 4(5), October-November, 11-19. Retireved April, $10^{\text {th }}, 2014$ from http://google.co.id/

Benk, Serkan, Tamer Budak, \& Ahmet Ferda Cakmak. (2012, January). Tax Profesionals Perceptions of Tax Fairness:Survey Evidence in Turkey. International Journal of Business and Social Science, 3(2), Special Issue, 112-117.

Das-Gupta, Arindam. (2014). The Economic Theory of Tax Compliance with Special Reference to Tax Compliance Cost. Retireved 18 April 2015, from http://www.nipfp.org.in/media/medialibrary/2013/04/wp04_nipfp_013.pdf

Eriksen, K., \& Fallan, L. (1996). Tax Knowledge and attitudes Towards Taxation; A Report on a Quasi- experiment. Journal of Economic Psychology, 17, 387-402. http://dx.doi.org/10.1016/0167-4870(96)00015-3

Gerbing, M. D. (1988). An Empirical Study of Taxpayer Perceptions of Fairness. Unpublished PhD Thesis, University of Texas.

Hofmann, Eva, Erik Hoelzl, \& Erich Kirchler. (2008). Preconditions of Voluntary Tax Compliance: Knowledge and Evaluation of Taxation, Norms, Fairness, and Motivation to Cooperate. Z Psychol, 216(4), 209-217. http://dx.doi.org/10.1027/0044-3409.216.4.209

Iyoke, C. A. et al. (2006). Teachers' Attitude is Not an Impediment to Adolescent Sexuality Education in Enugu, Nigeria. African Journal of Reproductive Health/La Revue Africaine de la Santé Reproductive, 10(1), 81-90. http://dx.doi.org/10.2307/30032447

Kamleitner, Bernadette, Christian Korunka, \& Erich Kirchler. (2012). Tax Compliance of Small Business Owners: A Review. International Journal of Entrepreneurial Behaviour \& Research, 18(3), 330-351. http://dx.doi.org/10.1108/13552551211227710 
Kołodziej, Sabina. (2011). The Role of Education in Forming Voluntary Tax Compliance. General and Professional Education 1, 22-25. Retrieved 12 April 2014, from http://genproedu.com/paper/2011-01/full_022-025.pdf

Marti, Lumumba Omweri, \& Migwi S., Wanjohi. (2011). Taxpayers Attitudes and Tax Compliance Behaviour in Kenya, How the Taxpayers' Attitudes Influence Compliance Behavior among SMEs Business Income Earners in Kerugoya Town, Kirinyaga District. African Journal of Business \& Management (AJBUMA), 1(2010), 112-122. Retrieved from $h$ ttp://www.aibuma.org/journal/index.htm

Mohd, R. P. (2005). Does Tax Knowledge Matters In Self-Assessment Systems? Evidence from Malaysian Tax Administrative. Journal of American Academy of Business, 80-84.

Mukasa, Joseph. (2011). Tax Knowledge, Perceived Tax Fairness And Tax Compliance in Uganda The Case Of Small And Medium Income Taxpayers in Kampala Central Division, Dissertation, Makerere University, Uganda.

Mukhlis, Imam, Sugeng Hadi Utomo, \& Yuli Soesetyo. (2013, March). Increasing Tax Compliance Through Strengtheing Capacity of Education Sector for Export Oriented SMEs Handicarft Field in East Java Indonesia. European Scientific Journal, 10(7), 170-184.

Niemirowski, P., Wearing, A. J., Baldwin, S., Leonard, B., \& Mobbs, C. (2002). The influence of tax Related Behaviours, Beliefs, Attitudes and Values on Australian Taxpayer Compliance. Is Tax Avoidance Intentional and How Serious an Offence is it?. University of New South Wales, Sydney.

Palil, Mohd Rizal, \& Ahmad Fariq Mustapha. (2011). Determinants of Tax Compliance in Asia: A case of Malaysia. European Journal of Social Sciences, 24(1), 7-32.

Richardson, S., \& Sawyer, A. (2001). A Taxonomy of The Tax Compliance Literature: Further findings, Problems and Prospects. Australian Tax Forum, 16, 137-320.

Saad, Natrah. (2011). Fairness Perceptions and Compliance Behaviour: Taxpayers Judgments in Self-Assessment Environments. A thesis submitted in fulfilment of the Requirements for the Degree of Doctor of Philosophy in Taxation in the University of Canterbury

Simanjutak, T. H., \& Imam Mukhlis. (2012, September). Analysis of Tax Compliance and Impacts on Regional Budgeting and Public Welfare. International Journal of Administrative Science \& Organization, 19(3), 194-205.

Wenzel, M. (2003). Tax Compliance and the Psychology of Justice: Mapping the Field. In Braithwaite V. (Ed.), Taxing democracy: Understanding tax avoidance and evasion. Ashgate (pp. 41-69). Hants, UK. 